\title{
Rancangan Sistem Pendeteksian Paspor Palsu: Solusi Pemeriksaan Keimigrasian di Indonesia
}

\author{
Wilonotomo ${ }^{\mathrm{a} 1}$, Bagas Hidayat Putra ${ }^{\mathrm{a} 2}$, Ridwan Arifina ${ }^{\mathrm{a}}$ \\ ${ }^{a}$ Manajemen Teknologi Keimigrasian, Politeknik Imigrasi \\ Jalan Raya Gandul No.4, Gandul-Cinere, Depok \\ ${ }^{1}$ wilo@poltekim.ac.id \\ ${ }^{2}$ bangbgs @gmail. com \\ ${ }^{3}$ ridwan.arifin@poltekim.ac.id
}

\begin{abstract}
Abstrak
Penelitian ini bertujuan untuk menjawab secara empiris salah satu tantangan terbesar yang dihadapi keimigrasian dalam hal penerapan proses pemeriksaan keimigrasian dalam pendeteksian paspor palsu terkait teknologi informasi yang diterapkan oleh Direktorat Jenderal Imigrasi di TPI. Tema yang dipilih adalah implementasi cara kerja petugas imigrasi di TPI mengidentifikasi paspor palsu melalui APK dalam pemeriksaan keimigrasian dan cara kerja kesisteman APK di TPI dalam mengidentifikasi paspor palsu. Pembahasan yang diangkat pada tema ini adalah ketimpangan permasalahan pemalsuan paspor yang tidak terdeteksi oleh sistem BCM karena belum memiliki sistem pendeteksian paspor palsu dan ditambah dengan fakta bahwa mayoritas petugas imigrasi sebagai Aparatur Sipil Negara (ASN) yang ditugaskan di TPI pun merupakan pegawai baru yang belum pernah mendapatkan pelatihan pemeriksaan dokumen palsu atau document fraud examination training untuk menganalisis fitur keamanan. Penelitian ini menggunakan metode penelitian kualitatif deskriptif yang bertujuan untuk memberikan hasil evaluasi terhadap sistem BCM yang telah dianalisa secara deskriptif dari berbagai sumber. Hasil pengujian dalam penelitian menunjukkan bahwa konsep teknologi informasi tersebut telah terintegrasi dengan sistem aplikasi untuk proses pemeriksaan keimigrasian di TPI Bandara Internasional di Indonesia, tetapi belum dapat mendeteksi paspor palsu. Kesimpulan yang didapatkan dalam penelitian ialah telah ditemukannya informasi detil mengenai cara kerja petugas imigrasi dalam mendeteksi paspor palsu serta bagaimana cara kerja sistem APK di TPI dalam mengidentifikasi paspor palsu dalam proses pemeriksaan keimigrasian yang hingga saat ini belum dapat terealisasikan. Riset ini memberikan rekomendasi sebuah rancangan sistem pendeteksian paspor palsu yang dipasang di sistem BCM yang mencakup backend dan frontend.
\end{abstract}

Kata kunci: pemeriksaan keimigrasian, pendeteksian paspor palsu, teknologi informasi, rancangan sistem pendeteksian paspor palsu

\section{An Adoption of Auto-Detection System of Falsified Passports: A Solution for Immigration Control in Indonesia}

\begin{abstract}
This research aims to answer empirically one of the biggest challenges faced by immigration in terms of implementing the immigration control process in detecting falsified passports related to information technology implemented by the Directorate General of Immigration at TPI. The theme chosen was the implementation of the workings of immigration officers at TPI to identify falsified passports through APK in immigration control and how the APK system at TPI worked in identifying falsified passports. The discussion raised on this theme is the inequality of the problem of passport forgery that is not detected by the BCM system because it does not have a falsified passport detection system and is added to the fact that the majority of immigration officers as State Civil Apparatus (ASN) assigned to TPI are also new employees who have never get document fraud examination training to analysing security features. This research uses descriptive qualitative research methods that aim to provide evaluation results of the BCM system that have been analysing descriptively from various sources. The test results in the study show that the information technology concept has been integrated with the application system for the immigration control process in TPI of International Airport in Indonesia, but has not been able to detect falsified passports. The conclusion obtained in the research is that detailed information has been found about how immigration officers work in detecting falsified passports and how the APK system at TPI in identifying falsified passports in the immigration control process has yet to be realized. This research provides
\end{abstract}


recommendations for a falsified passport detection system design installed in the BCM system that includes the backend and frontend.

Keywords: immigration control, detecting falsified passport, information technology, falsified passport detection system design

\section{Pendahuluan}

Perkembangan teknologi informasi dan komunikasi dapat merambah ke sistem keamanan pelayanan publik di bidang keimigrasian yang terus memanfaatkan kemajuan teknologi. Perkembangan teknologi yang semakin maju menuntut manusia untuk menggunakan manfaat dari suatu teknologi [1]. Perkembangan teknologi tersebut pun secara tidak langsung mendorong manusia agar dapat lebih giat dan kreatif dalam mengembangkan teknologi yang lebih canggih, efektif, praktis, serta efisien bagi kehidupan serta lingkungannya sehari-hari [2]. Peningkatan sistem keamanan berbasis teknologi informasi dan komunikasi di Tempat Pemeriksaan Imigrasi (TPI) Indonesia diterapkan dalam rangka menciptakan keamanan nasional demi menjaga tegaknya kedaulatan negara.

Keamanan merupakan salah satu aspek yang sangat penting dalam pertukaran data dan informasi [3], sehingga sangat diperlukannya implementasi peningkatan sistem keamanan. Fungsi peningkatan sistem kemanan tersebut memiliki kaitan dengan teori fraud awareness, yaitu menghindari kecurangan yang dapat terjadi akibat pemalsuan dokumen demi kepentingan pribadi atau kelompok yang dapat mengancam keamanan negara, lalu dijadikan pembenaran bahwa kecurangan merupakan hal biasa yang boleh dilakukan [4].

Berdasarkan Undang-Undang Nomor 25 Tahun 2009, pasal 23 ayat (4) tentang Pelayanan Publik, disebutkan bahwa:

"Penyelenggara berkewajiban mengelola Sistem Informasi yang terdiri atas Sistem Informasi Elektronik atau Non Elektronik yang sekurang-kurangnya meliputi, profil penyelenggara, profil pelaksana, standar pelayanan, maklumat pelayanan, pengelola pengaduan dan penilaian kinerja [5]".

Berkaitan dengan ketentuan tersebut, Direktorat Jenderal Imigrasi telah mengimplementasikan pembaruan Sistem Informasi dan Manajemen Keimigrasian (SIMKIM) sebagai bagian dari pelayanan publik keimigrasian di TPI. Secara luas, penerapan SIMKIM sudah dilakukan di seluruh Unit Pelaksana Teknis Keimigrasian, baik di Kantor Imigrasi, TPI maupun Perwakilan Imigrasi di Luar Negeri [6]. SIMKIM merupakan salah satu penerapan teknologi informasi yang berinteraksi langsung dengan tata kelola teknologi informasi, yang kemudian dapat memengaruhi kinerja organisasi secara keseluruhan [7].

Contoh penerapan SIMKIM adalah dengan dibangunnya sistem Border Control Management (BCM) di TPI di seluruh Indonesia. Sistem BCM adalah untuk mendukung pemeriksaan keimigrasian di bandara internasional, pelabuhan internasional, dan Pos Lintas Batas Negara (PLBN) agar lebih akurat, efektif, dan efisien.

Aplikasi Perlintasan Keimigrasian (APK) atau yang disebut dengan sistem BCM merupakan sistem manajemen pengawasan wilayah perbatasan yang berbasis teknologi untuk menyeleksi dan mengawasi seluruh kegiatan perlintasan orang di TPI [8]. APK berfungsi untuk membantu petugas pemeriksa dalam pengidentifikasian dokumen perjalanan, paspor, dan visa. Selain itu, sistem BCM berfungsi untuk melakukan pengecekan terkait pencegahan dan penangkalan di TPI terhadap orang yang sedang bermasalah dengan hukum [9].

Dengan adanya APK, petugas Imigrasi dapat dengan mudah merekam dan menentukan apakah orang yang ingin melewati TPI termasuk dalam daftar pencegahan dan penangkalan atau tidak, sehingga prinsip kebijakan selektif (Selective Policy) dapat diimplementasikan. Hal tersebut dapat mengurangi angka kemungkinan masuknya warga negara asing dalam daftar penangkalan atau yang dapat memberikan dampak buruk untuk negara Indonesia, serta mengurangi angka kemungkinan keluarnya warga negara Indonesia yang masuk daftar pencegahan.

Melalui APK, petugas melakukan pemindaian paspor penumpang pada halaman biodata paspor yang terdiri atas data, foto, dan kolom Machine Readable Zone (MRZ). Paspor penumpang dipindai dengan alat pemindai (scanner) khusus yang dapat membaca data paspor, merekam foto, serta data MRZ. Paspor yang dapat dipindai hanya paspor yang sesuai dengan standar produk dan fitur keamanan yang diterbitkan oleh International Civil Aviation Organization (ICAO) dalam Doc. 9303 [10]. Akan tetapi, APK dan alat pemindai belum dapat membaca data dalam chip paspor elektronik milik penumpang.

APK secara otomatis melakukan pengecekan terhadap data penumpang, mencakup data dokumen perjalanan, serta data nama penumpang dalam daftar pencegahan dan penangkalan melalui sistem Enhance Cekal System (ECS) yang hasilnya akan muncul pada kolom "Result". Namun, pangkalan data penumpang tersebut bukan data data pencegahan kriminal di dunia atau international watchlist, melainkan hanya data dokumen perjalanan yang hilang dan dicuri dalam tercatat sistem I-24/7 SLTD (Stolen and Lost Travel Documents) milik INTERPOL [11].

Selain itu, APK yang dikembangkan oleh Direktorat Jenderal Imigrasi Indonesia belum memiliki sebuah sistem pendeteksian paspor palsu baik untuk paspor Indonesia maupun paspor asing. Sebab, kondisi kesisteman seperti ini dapat mengancam keamanan nasional terhadap kejahatan internasional. Pemalsuan paspor merupakan sebuah kejahatan yang dilakukan dengan cara mengganti, mengubah sebagian atau secara keseluruhan dari sebuah paspor atau menggunakan informasi palsu untuk menerima paspor [12]. Pemalsuan paspor termasuk ke dalam kejahatan transnasional yang harus dihadapi secara penuh kesadaran dalam dunia yang tengah mengalami proses kemajuan dalam perkembangan teknologinya seperti saat ini [13].

Dalam beberapa kasus pemalsuan paspor, tidak sedikit kejahatan penipuan oleh penyemu atau impostor (penggunaan paspor orang lain) yang berasal 
menggunakan paspor curian. Penipuan seperti ini disebut juga dengan look-alike fraud (penipuan yang mirip) atau identity fraud (penipuan identitas). Penipuan ini dapat terjadi jika paspor resmi dan sah milik seseorang diberikan kepada orang lain secara sukarela. Misalnya, paspor palsu digunakan untuk masuk ke suatu negara untuk melakukan kejahatan. Secara tradisional paspor memiliki tiga persyaratan komponen keamanan, yaitu:

1) Keaslian dan integritas dokumen (beserta datanya);

2) Otorisasi, tergantung pada situasi penggunaan (private key); dan

3) Cocok atau sesuai dengan biometriknya [14].

Secara resmi, menurut ICAO, terdapat lima jenis pemalsuan paspor, yakni counterfeit documents (penggunaan paspor palsu sepenuhnya), forged documents (penggunaan paspor dengan teknik ditempa), tampering with the contactless IC (teknik merusak chip kontak), imposters (penggunaan paspor milik orang lain), dan pseudo documents (penggunaan paspor semu) [15].

Pemalsuan paspor tersebut tidak terdeteksi oleh sistem BCM karena belum ada sistem pendeteksian paspor palsu. Mayoritas petugas imigrasi sebagai Aparatur Sipil Negara (ASN) yang ditugaskan di TPI merupakan pegawai baru yang belum pernah mendapatkan pelatihan pemeriksaan dokumen palsu atau document fraud examination training untuk menganalisis fitur keamanan paspor [16]. Dalam implementasinya, komponen tersebut merupakan salah satu kompetensi dasar yang wajib dimiliki oleh petugas imigrasi di TPI [17].

Secara umum, belum pernah ada penelitian mengenai rancangan atau rekomendasi sistem pendeteksian paspor palsu di TPI. Namun, ada penelitian yang membahas evaluasi dan pengembangan sebuah sistem pendeteksian kesesuaian dokumen digital proposal yang dilakukan dengan metode extended weighted tree similarity [18]. Penelitian tersebut menemukan beberapa poin permasalahan dalam sistem yang menghasilkan suatu perencanaan pengembangan sistem yang akan dilakukan lebih lanjut guna meningkatkan kualitas dan kinerja sistem tersebut.

Penelitian ini memiliki tujuan utama untuk mengetahui bagaimana cara kerja petugas imigrasi di TPI dalam mengidentifikasi paspor palsu melalui APK serta untuk mengetahui bagaimana cara kerja kesisteman APK di TPI dalam mengidentifikasi paspor palsu. Pada hasil akhirnya akan ditemukan sebuah rancangan sistem pendeteksian paspor palsu yang diharapkan dapat menjadi sebuah solusi dalam pemeriksaan keimigrasian di Indonesia.

Berdasarkan latar belakang tersebut, penelitian ini telah menjawab fenomena di atas dengan rumusan masalah sebagai berikut:

1) Bagaimana petugas imigrasi di TPI mengidentifikasi paspor palsu melalui APK dalam pemeriksaan keimigrasian?

2) Bagaimana cara kerja kesisteman APK di TPI dalam mengidentifikasi paspor palsu?

\section{Metodologi Penelitian}

Metode penelitian yang dilakukan dalam penelitian ini adalah metode penelitian kualitatif yang meliputi studi pustaka, konsultasi, dan rekomendasi pemodelan sistem. Tiga metode penelitian telah dilaksanakan sesuai dengan kerangka kerja penelitian seperti berikut:

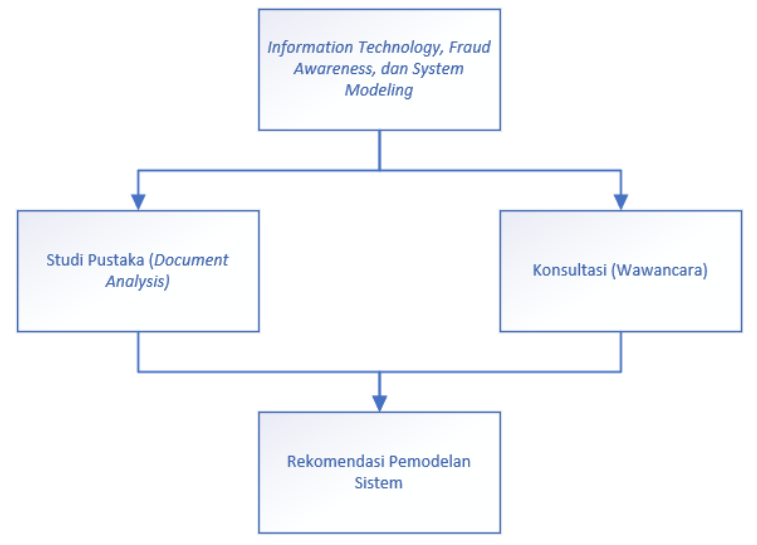

Gambar 1. Kerangka Kerja Penelitian

Tahap pertama adalah dengan melakukan kajian terhadap 3 konsep teori, yakni Information Technology, Fraud Awareness, dan System Modeling.

Tahap kedua adalah dengan studi Pustaka, yaitu pengumpulan data dengan teknik document analysis [19] mengumpulkan literatur, jurnal, dan bahan penelitian lainnya yang memiliki kaitan dengan judul penelitian.

Tahap ketiga adalah konsultasi, yaitu melakukan wawancara dengan petugas imigrasi yang pernah atau sedang bertugas di TPI, serta memiliki pemahaman akan teknologi informasi sehingga dapat didapatkannya informasi yang dapat mendukung penelitian.

Tahap keempat adalah hasil penelitian yang berupa rekomendasi rancangan sistem pendeteksian paspor palsu yang telah dibuat dalam bentuk diagram alir atau flowchart. Hasil rekomendasi rancangan diagram alir tersebut dibuat berdasarkan konsep System Development Life Cycle (SDLC). Adapun konsep SDLC yang digunakan pada penelitian ini berada dalam batasan communication, planning, dan modelling.

Penelitian ini menggunakan teknik pengumpulan data wawancara dan studi dokumentasi yang dilaksanakan dengan fokus dua lokasi penelitian TPI Bandara Internasional Soekarno-Hatta dan TPI Bandara Internasional Sam Ratulangi sebagai contoh sampel.

\section{HASIL DAN PEMBAHASAN}

\section{A. Kajian Teori Sistem Identifikasi Paspor Palsu}

\section{1) Teori Information Technology}

Teknologi informasi dan komunikasi merupakan salah satu bagian utama yang saat ini menjadi acuan dalam perkembangan hidup manusia dalam berbagai aspek kehidupan yang menekankan sebuah peran komunikasi terpadu dan integrasi antara telekomunikasi, komputer, serta perangkat lunak [20]. Secara umum, teknologi informasi komunikasi dapat diartikan sebagai ilmu pengetahuan dalam bidang informasi berbasis komputer dan digital dengan perkembangan yang pesat [21]. Heinich menekankan bahwa teknologi informasi 
merupakan segala bentuk penggunaan atau pemanfaatan komputer dan internet untuk pembelajaran. Bentuk penggunaan/pemanfaatan teknologi informasi yakni:

1. Tutorial, merupakan progam yang dalam penyampaian materinya dilakukan secara tutorial, yakni suatu konsep yang disajikan dengan teks, gambar baik diam atau bergerak, dan grafik;

2. Praktik dan dan latihan (drill and practice), yaitu untuk melatih subjek sehingga memiliki kemahiran dalam suatu keterampilan atau memperkuat penguasaa suatu konsep. Progam ini biasanya menyediakan serangkaian soal atau pertanyaan;

3. Simulasi (simulation), yaitu format ini bertujuan untuk mensimulasikan tentang suatu kejadian yang sudah terjadi maupun yang belum dan biasanya berhubungan dengan suatu resiko, seperti pesawat akan jatuh atau menabrak, terjadinya malapetaka dan sebagainya;

4. Percobaan atau eksperimen, format ini mirip dengan format stimulasi, namun lebih ditujukan pada kegiatan-kegiatan eksperimen;dan

5. Permainan (game), yaitu mengacu pada proses pembelajaran dengan sebuah program berformat [22].

Teori tersebut menjelaskan bahwa teknologi informasi telah menjadi acuan utama bagi kehidupan manusia sehari-hari sebagai alat bantu untuk meningkatkan kualitas kinerja dalam berbagai bidang. Hal tersebut telah terimplementasikan dalam bidang keimigrasian, yakni imigrasi memiliki peran penting dalam hal pemeriksaan keimigrasian yang bergantung pada satu sistem teknologi informasi terpusat, yaitu SIMKIM yang berintegrasi dengan salah satu sistem pemeriksaan keimigrasian di TPI, yakni BCM.

\section{2) Sistem Informasi Manajemen Keimigrasian (SIMKIM)}

SIMKIM adalah sistem teknologi informasi dan komunikasi yang digunakan untuk mengumpulkan, mengolah dan menyajikan informasi guna mendukung operasional, manajemen, dan pengambilan keputusan dalam melaksanakan Fungsi Keimigrasian.

SIMKIM pertama kali diterapkan pada tahun 2007 dan terus berkembang hingga saat ini. Fungsi dan tujuan kerja dari SIMKIM adalah untuk mencapai optimalisasi kinerja secara efektif, efisien dan professional [23]. Melalui SIMKIM, kinerja Direktorat Jenderal Imigrasi akan semakin optimal karena SIMKIM dapat mengintegrasikan seluruh aplikasi di fungsi keimigrasian dengan baik. Layaknya sebuah sistem informasi manajemen, SIMKIM dapat mengumpulkan dan menyimpan data yang disimpan dengan pengamanan optimal dalam pusat data keimigrasian serta didukung dengan Disaster Recovery Center (DRC) sebagai backup data. Selain mengumpulkan data dan menyimpannya, SIMKIM juga dapat mengambil data-data tersebut kembali dan dapat diakses oleh pihak Direktorat Jenderal Imigrasi sesuai dengan tugas dan fungsinya masing-masing.

\section{3) Border Control Management (BCM)}

Sistem BCM atau APK merupakan bagian dari SIMKIM substantif berbasis teknologi informasi dan komunikasi yang dibangun dan dikembangkan oleh
Direktorat Jenderal Imigrasi. Sistem ini untuk mendukung tugas pokok dan fungsi dalam perekaman data dan pemeriksaan keimigrasian terhadap setiap orang yang masuk dan keluar wilayah Indonesia melalui Tempat Pemeriksaan Imigrasi (TPI)

Sistem BCM terintegrasi dengan sistem aplikasi seperti sistem pencegahan dan penangkalan atau ECS, sistem data perlintasan atau PMS, sistem penerbitan Dokumen Perjalanan Republik Indonesia (DPRI), sistem Izin tinggal, dan sistem VISA untuk mendukung kegiatan pemeriksaan keimigrasian di TPI [24].

\section{4) Teori Fraud Awareness}

Penipuan dilakukan dengan cara-cara yang hampir tidak dapat dilacak sehingga pelakunya tidak dapat dikenal, meskipun berbagai upaya dilakukan oleh aparat penegak hukum untuk menemukan dan menghukum pelakunya. Munculnya era digitalisasi yang mencakup luasnya perkembangan teknologi informasi seperti sekarang ini telah menyebabkan semakin beragamnya model atau bentuk kejahatan penipuan maupun pemalsuan yang dilakukan oleh oknum kejahatan yang tidak bertanggung jawab. Dengan adanya perkembangan teknologi informasi dan komunikasi tersebut, maka sangat diperlukan peningkatan akan kesadaran terhadap pemalsuan suatu barang, dokumen, dan hal lainnya, khususnya yang berbasis teknologi informasi [25]. Sebab, dengan adanya perkembangan teknologi seperti sekarang ini akan meningkatkan kasus pemalsuan yang dilakukan oleh orang-orang yang memanfaatkan teknologi dengan cara yang ilegal [26].

Dalam implementasi dan keterkaitannya dengan keimigrasian, kejahatan penipuan yang sering terjadi ialah kejahatan dalam bentuk pemalsuan paspor. Berdasarkan fenomena tersebut sangat dibutuhkan sebuah implementasi nyata sebagai tindak pencegahan munculnya kejahatan baru terkait pemalsuan paspor, salah satunya adalah dengan cara meningkatkan kualitas petugas imigrasi di TPI dan perancangan rekomendasi skema sistem pendeteksian paspor palsu.

\section{5) Dokumen Perjalanan Republik Indonesia}

Dokumen perjalanan atau paspor sangat dibutuhkan sebagai syarat utama untuk melakukan perjalanan antarnegara. Di dalam ICAO Annex 9 - Facilitiation (Border Controls and Procedures) dijelaskan bahwa Dokumen Perjalanan adalah paspor atau document of identity resmi lainnya yang diterbitkan oleh negara atau organisasi yang digunakan oleh pemegang (yang berhak) untuk melakukan perjalanan internasional [27].

Di Indonesia, Dokumen Perjalanan disebut dengan Dokumen Perjalanan Republik Indonesia. Dokumen Perjalanan Republik Indonesia adalah Paspor Republik Indonesia dan Surat perjalanan laksana paspor. Paspor Republik Indonesia adalah Dokumen yang dikeluarkan oleh pemerintah Republik Indonesia untuk Warga Negara Indonesia untuk melakukan perjalanan antarnegara yang berlaku selama jangka waktu tertentu.

Paspor terdiri atas paspor diplomatik, paspor dinas, dan paspor biasa. Paspor biasa diperuntukan hanya untuk Warga Negara Indonesia dan dapat diajukan pada kantor 
imigrasi di wilayah Indonesia serta perwakilan imigrasi di luar negeri [28] dengan melampirkan persyatan permohonan paspor sesuai dengan yang dijelaskan pada peraturan perundang-undangan. Paspor diterbitkan oleh Menteri Hukum dan HAM atau pejabat imigrasi di kantor imigrasi atau oleh pejabat imigrasi yang diberi wewenang untuk menjadi atase pada perwakilan Republik Indonesia. Dalam hal belum terdapatnya pejabat imigrasi pada perwakilan Republik Indonesia, penerbitan paspor dapat dilimpahkan kepada Pejabat Dinas Luar Negeri.

Penerbitan paspor merupakan salah satu bagian dari fungsi keimigrasian yang dijalankan oleh Direktorat Jenderal Imigrasi yaitu pelayanan keimigrasian. Hal ini dilakukan untuk memfasilitasi masyarakat yang ingin melakukan perjalanan antar negara dengan cara menerbitkan paspor yang digunakan sebagai dokumen resmi dalam melakukan perjalanan antar negara seperti yang tertulis di dalam Annex 9 - Facilitiation (Border Controls and Procedures).

\section{6) Tempat Pemeriksaan Imigrasi (TPI)}

TPI adalah tempat pemeriksaan di pelabuhan laut, bandara udara, pos lintas batas, atau tempat lain sebagai tempat masuk dan keluar wilayah Indonesia [29]. TPI merupakan pintu gerbang negara Indonesia, karena setiap orang yang ingin masuk atau keluar wilayah Indonesia wajib melewati pemeriksaan di TPI dengan membawa Dokumen Perjalanan yang sah dan masih berlaku.

Terdapat 182 TPI yang menyebar diseluruh wilayah Indonesia, dengan rincian sebanyak 90 TPI laut, 37 TPI Udara, 11 Pos Lintas Batas Internasional, dan 44 Pos Lintas Batas Tradisional [30]. Banyaknya pembangunan TPI disebabkan karena Letak Geografis dari wilayah Indonesia yang terdiri dari pulau-pulau dan lautan. Indonesia sebagai negara kepulauan memiliki garis pantai yang sangat panjang, bahkan beberapa pulau milik Indonesia berbatasan langsung dengan negara lain. Pelaksanaan fungsi keimigrasian di wilayah perbatasan merupakan kewenangan instansi imigrasi atau Direktorat Jenderal Imigrasi. Oleh karena itu, untuk meningkatkan pelayanan dan pengawasan Keimigrasian maka Direktorat Jenderal Imigrasi membangun TPI untuk menghindari orang yang masuk atau keluar di luar Indonesia secara ilegal.

\section{7) Petugas Imigrasi TPI}

Merupakan sumber daya manusia yang berada pada ruang lingkup Direktorat Jenderal Imigrasi dan memiliki tugas sebagai pemeriksa dalam hal pemeriksaan keimigrasian terhadap lalu lintas orang di TPI. Berdasarkan survei penilaian yang dilakukan oleh National Careers United Kingdom, seorang petugas imigrasi di TPI harus memiliki beberapa keterampilan atau keahlian khusus guna bertugas secara maksimal di TPI, beberapa keahlian tersebut antara lain:

1. Memiliki keahlian komunikasi verbal yang baik;

2. Memiliki keahlian customer service skill;

3. Memiliki keahlian berbicara Bahasa inggris (wajib);

4. Memiliki tingkat konsentrasi yang baik dalam hal bekerja;dan

5. Handal dalam menggunakan perangkat komputer.
Selain keahlian, seorang petugas imigrasi di TPI memiliki beberapa poin uraian tugas yang umum dan fundamental, seperti:

1. Melaksanakan pemeriksaan keimigrasian dengan mengawasi lalu lintas orang, memeriksa paspor serta visa;

2. Melakukan wawancara singkat dengan menanyakan beberapa pertanyaan dasar seperti apa tujuannya di negara ini dan lainnya;dan

3. Melakukan pengumpulan informasi dengan mengawasi lalu lintas orang serta informasi detil mengenai beberapa orang yang memang terindikasi menjadi target pencarian [31].

Perlu ditegaskan kembali bahwa petugas Imigrasi melaksanakan tugasnya di TPI ialah bukan hanya untuk aspek pelayanan, melainkan juga untuk melakukan aspek pemeriksaan. Maka, petugas imigrasi di TPI memiliki tugas dan tanggung jawab yang berat dalam hal memeriksa sedetil mungkin paspor dan visa milik warga negara asing maupun warga negara Indonesia yang keluar dan masuk wilayah Indonesia [32].

Berdasarkan sebuah hasil studi yang dijelaskan dalam European Intelligence and Security Informatics Conference, hingga saat ini para petugas imigrasi di TPI pun masih seringkali mengandalkan pengalaman, indera dan intuisi mereka dalam pemeriksaan keimigrasian untuk mengidentifikasi paspor palsu [33]. Walaupun sudah terdapat teknologi di perbatasan, tidak menutup kemungkinan terkadang terjadi kesalahan pada sistem atau database yang tidak dapat muncul secara otomatis sehingga menghambat proses pemeriksaan keimigrasian.

Mayoritas petugas imigrasi TPI di Indonesia belum memiliki pengalaman yang cukup untuk mengidentifikasi paspor palsu dalam proses pemeriksaan keimigrasian, bahkan tidak sedikit juga yang belum pernah mengikuti pelatihan pemeriksaan dokumen palsu dikarenakan banyaknya jumlah ASN imigrasi baru yang ditempatkan di TPI pada dua tahun terakhir.

\section{8) Teori System Modelling}

Menurut Azhar Susanto, sistem adalah kumpulan dari sub sistem, bagian, dan komponen atau apapun baik fisik ataupun non fisik yang saling berhubungan satu sama lain dan dapat bekerja sama untuk mencapai satu tujuan tertentu yang terbuat dari beberapa pemodelan atau konsep pada suatu perangkat lunak [34].

\section{9) Perangkat lunak (software)}

Perangkat lunak adalah program komputer yang berhubungan dengan dokumen perangkat lunak (seperti dokumen persyaratan, model desain, dan cara menggunakannya. Sebuah program komputer tanpa terasosiasi dengan dokumentasinya belum dapat disebut perangkat lunak. Perangkat lunak biasanya disebut juga dengan sebuah sistem perangkat lunak. Sistem mengacu pada kumpulan komponen yang saling berhubungan yang memiliki tujuan yang dicapai. Pada awal pengembangan perangkat lunak, para pembuat program (programmer) langsung melakukan proses coding perangkat lunak tanpa menggunakan prosedur atau tahapan pengembangan perangkat lunak. Setelah itu ditemukanlah kendala- 
kendala seiring dengan perkembangan skala sistem-sistem perangkat yang semakin besar [35].

\section{0) Database}

Database secara logis terkait pengumpulan data dan deskripsi data, yang dirancang untuk menemukan informasi yang dibutuhkan oleh organisasi. Dalam merancang database, salah satu hal yang perlu diperhatikan ialah efisiensi. Banyaknya data yang redudansi dapat mengurangai efisiensi pada database sehingga perlu dilakukan normalisasi. Database ini digunakan tidak hanya oleh satu orang maupun satu departemen, database dapat digunakan oleh seluruh departemen dalam perusahaan. Database ini akan menjadi sumber data yang digunakan secara bersama dalam perusahaan [36].

\section{1) System Development Life Cycle (SDLC)}

SDLC adalah proses mengembangkan atau mengubah sistem perangkat lunak menggunakan model dan metode yang digunakan orang untuk mengembangkan sistem perangkat lunak sebelumnya (berdasarkan best practice atau cara-cara yang sudah teruji baik). Seperti proses metamorphosis, kupu-kupu yang indah membutuhkan beberapa tahap untuk dilalui, sama halnya dengan membuat perangkat lunak, memiliki alur tahapan yang dilalui agar menghasilkan perangkat lunak yang berkualitas [37].

\section{B. Pemodelan Sistem Identifikasi Paspor Palsu di BCM}

Pemanfaatan Sistem Informasi Manajemen Keimigrasian atau SIMKIM sejak tahun 2007 sudah berlaku hampir di seluruh unit pelaksana teknis (UPT) keimigrasian di Indonesia maupun di perwakilan RI di luar negeri. Salah satu UPT yang menerapkan pemanfaatan SIMKIM adalah kantor imigrasi yang membawahkan TPI di seluruh Indonesia dengan aplikasi BCM di tahun 2011 dan aplikasi APK versi 2 di tahun 2018.

Sistem BCM di TPI membuat pemeriksaan keimigrasian atau paspor yang lebih aman daripada pemeriksaan dengan cara manual. Sistem BCM secara otomatis melakukan pemeriksaan terhadap data dalam paspor dan data diri penumpang yang setiap kali melewati TPI. Petugas imigrasi di TPI dapat memanfaatkan keberadaan sistem BCM dalam pemeriksaan paspor tanpa mengabaikan nalurinya sebagai petugas pemeriksa keimigrasian.

Sistem BCM digunakan oleh petugas imigrasi di TPI yang memiliki kewenangan, tugas dan tanggung jawab dalam hal pemeriksaan, pengawasan, dan perekaman data lalu lintas orang yang masuk atau keluar wilayah Indonesia. Untuk menggunakan aplikasi sistem BCM, petugas pemeriksa keimigrasian wajib melakukan login dengan mengisi nama akun dan kata sandi atua username dan password. Kemudian petugas harus memilih lokasi TPI dan jenis pemeriksaan keimigrasian. Selain itu, saat pelaksanaan pemeriksaan keimigrasian di TPI, petugas imigrasi juga memiliki kewajiban untuk menjaga ketertiban antrean penumpang di konter imigrasi dan menginformasikan kepada penumpang untuk menyiapkan dokumen-dokumen yang diperlukan.

Dokumen yang disiapkan oleh penumpang adalah dokumen perjalanan yang sah dan masih berlaku paling singkat 6 (enam) bulan, visa yang sah dan berlaku kecuali yang termasuk dalam subjek bebas visa bagi orang asing, dan memiliki tiket kembali atau tiket terusan ke negara lain bagi orang asing.

Sistem BCM dapat membantu pemeriksaan keimigrasian di TPI dengan memberikan beberapa informasi terkait warga negara asing dan warga negara Indonesia yang melewati Tempat Pemeriksaan Imigrasi. Untuk mendapatkan informasi tersebut, petugas pemeriksa keimigrasian melakukan pemindaian MRZ yang terdapat di dalam halaman identitas pada paspor menggunakan Machine Reader Travel Document (MRTD).

Informasi yang ditampilkan pada sistem BCM meliputi dua hal, yaitu biodata penumpang dan data perjalanan penumpang. Informasi yang ditampilkan pada bagian biodata meliputi:

a. Nomor Dokumen Perjalanan;

b. Tipe Dokumen Perjalanan;

c. Negara yang Mengeluarkan;

d. Tanggal Habis Berlaku;

e. Nama Depan;

f. Nama Keluarga;

g. Jenis Kelamin;

h. Tanggal Lahir;dan

i. Kewarganegaraan.

Selanjutnya, sistem akan melakukan pengecekan data perjalanan dari orang tersebut, yang mencakup:

1. Data Dokumen Perjalanan;

2. Data Pergerakan Terakhir;dan

3. Nama Penumpang dalam Daftar Pencegahan dan Penangkalan melalui sistem ECS yang hasilnya akan muncul pada kolom result.

Alur tersebut berisi beberapa hal yang harus dilakukan oleh petugas imigrasi dalam melakukan pemeriksaan terhadap paspor milik penumpang yang akan melewati TPI. Ada beberapa tahapan yang harus dilakukan oleh petugas imigrasi dalam melakukan pemeriksaan paspor di TPI. Tahap tersebut dimulai dari pemindaian manual seperti pemeriksaan identitas, apakah paspor tersebut sah atau tidak, apakah pemilik paspor tersebut merupakan impostor atau bukan, hingga peneraan cap pada paspor tersebut.

Terdapat tujuh komponen pertanyaan dalam instrumen wawancara yang diberikan kepada responden terkait unsur BCM di TPI, yakni:

1. Bagaimana cara kerja sistem BCM di TPI Udara (tempat responden bertugas);

2. Apa ada kendala yang seringkali dialami pada BCM di TPI Udara (tempat responden bertugas);

3. Apakah sistem BCM dapat mendeteksi paspor palsu secara akurat;

4. Apa yang telah dilakukan oleh pihak imigrasi guna mengatasi kendala tersebut;

5. Apakah ada sebuah inovasi atau wacana perbaikan untuk mengatasi kendala tersebut; 
6. Apakah perlu adanya sebuah sistem pendeteksian paspor palsu pada sistem BCM;dan

7. Menurut saudara, apa saja komponen utama/fundamental yang diperlukan dalam sebuah sistem pendeteksian paspor palsu.

Menurut dua responden, ada komponen fundamental yang sangat diperlukan dalam membangun suatu sistem pendeteksian paspor palsu di TPI. Komponen tersebut ialah komponen document detection system yang cepat dan akurat dalam mendeteksi keaslian sebuah paspor. Selain itu, ada komponen non-teknis yang diperlukan, seperti diwajibkannya setiap petugas imigrasi di TPI untuk memiliki sertifikasi forensik paspor agar dapat lebih terjaminnya hasil kinerja dan kualitas pemeriksaan paspor di TPI.

Berdasarkan hasil wawancara, pada dasarnya proses pemeriksaan keimigrasian dengan sistem BCM dalam pendeteksian paspor palsu di TPI oleh petugas imigrasi belum berjalan dengan sangat maksimal keterbatasan keterbatasan sistem aplikasi, waktu proses pemeriksaan, serta kemampuan analisis pemeriksaan setiap petugas imigrasi yang berbeda-beda.

Hasil penelitian membuktikan bahwa jumlah petugas imigrasi TPI yang pernah mendapatkan pelatihan pemeriksaan dokumen palsu pun dapat terbilang sedikit. Hal tersebut secara tidak langsung dapat memengaruhi tindak kejahatan pemalsuan paspor yang melalui TPI akan terus meningkat. Pada prinsipnya, pemeriksaan keimigrasian di TPI sangat membutuhkan keberadaan sistem pendeteksian paspor palsu yang dapat terintegrasi dengan sistem BCM secara langsung dan realtime.

Penelitian ini menggambarkan rancangan sistem pendeteksian paspor palsu berdasarkan hasil pengumpulan data dengan metode analisis dokumen yang komprehensif dan detil dalam bentuk diagram alir.

Adapun diagram alir pendeteksi paspor palsu di APK terbagi menjadi empat bagian:

1. Diagram Alir urutan keberangkatan;

2. Diagram Alir aktivitas keberangkatan;

3. Diagram Alir urutan kedatangan;dan

4. Diagram Alir aktivitas kedatangan [38].

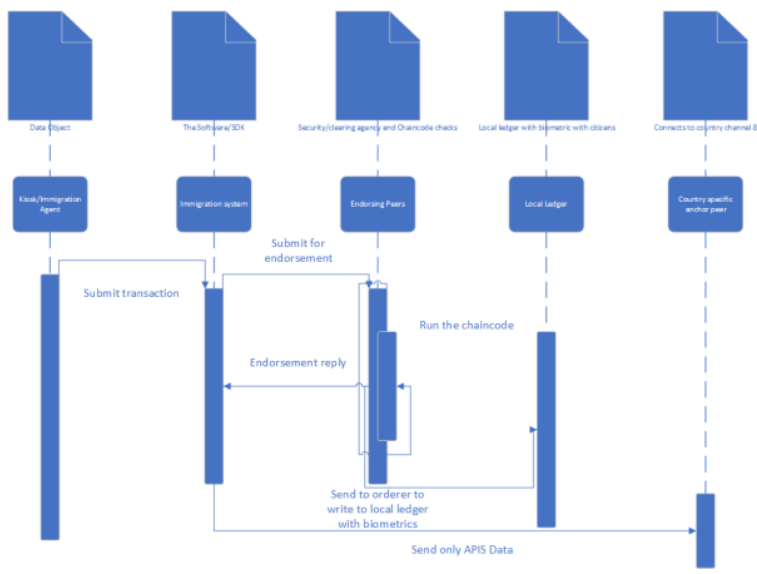

Gambar 2. Rekomendasi Rancangan Proses Pemeriksaan saat Keberangkatan (urutan back end), Adopsi dari Patel et al, 2018

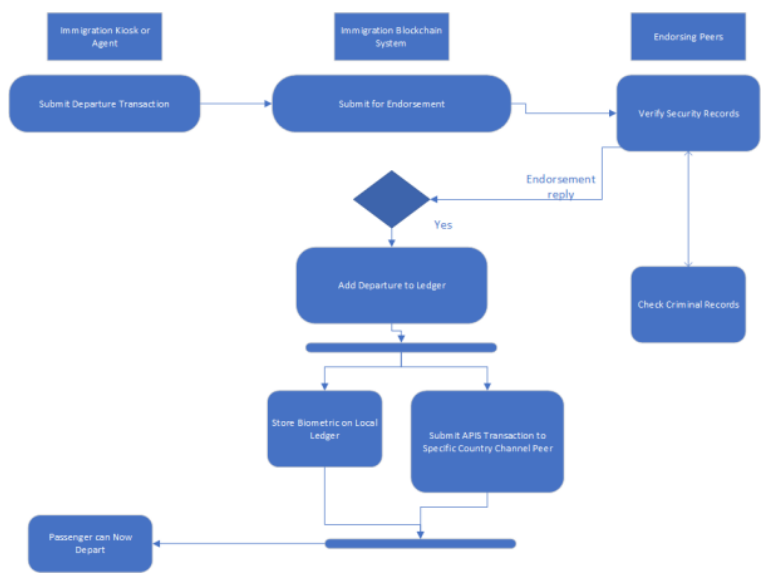

Gambar 3. Rekomendasi Rancangan Proses Pemeriksaan saat Kedatangan (aktivitas front end), Adopsi dari Patel et al, 2018

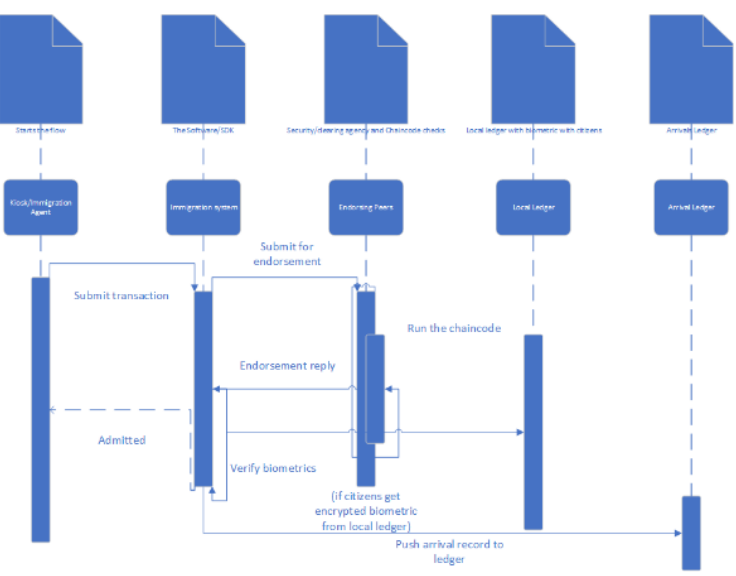

Gambar 4. Rekomendasi Rancangan Proses Pemeriksaan saat Kedatangan (urutan back end), Adopsi dari Patel et al, 2018

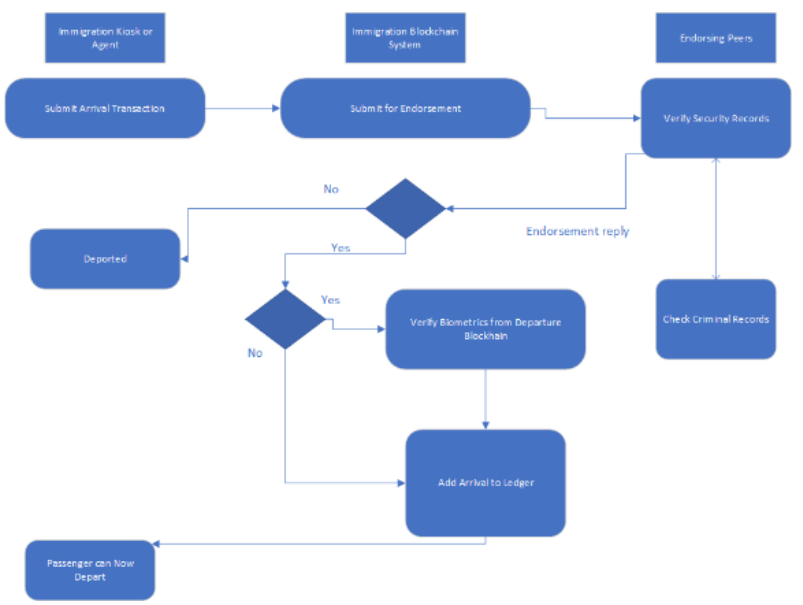

Gambar 5. Rekomendasi Rancangan Proses Pemeriksaan saat Kedatangan (aktivitas front end), Adopsi dari Patel et al, 2018

Empat diagram alir tersebut menjelaskan bagaimana alur sistem BCM akan bekerja dengan integrasi sistem terhadap pangkalan data paspor yang bekerja berdasarkan sistem manajemen pangkalan data atau database management system [39] (DBMS) dalam pendeteksian paspor palsu pada alur keberangkatan dan kedatangan penumpang. Masing-masing keberangkatan dan 
kedatangan terbagi menjadi 2 jenis yakni diagram berbasis front end (aktivitas) dan back end (urutan).

Pada gambar 2, 3, 4, dan 5 menjelaskan alur urutan dan aktivitas keberangkatan serta kedatangan yang memiliki sebuah local ledger yang berisi biometrik ataupun data dukung para penumpang yang akan melintas. Yang mana data dukung tersebut disediakan oleh Advanced Passenger Information System [40] (APIS).

Dalam ilmu teknologi informasi, front end merupakan kumpulan halaman-halaman situs atau aplikasi yang dapat diakses pengunjung, sedangkan back end merupakan suatu hak akses yang biasa disebut dengan CMS (content management system) atau dapat juga disebut dengan Admin Area yang berfungsi untuk memperbarui halamanhalaman front end. Maka, halaman back end pada umumnya hanya dapat diakses oleh pemilik atau pengelola dengan username dan password yang telah ditetapkan [41].

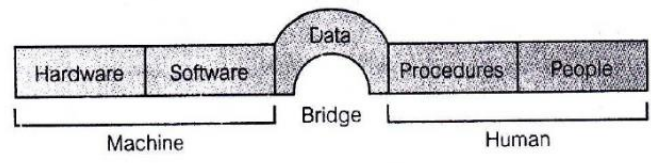

Gambar 6. Komponen DBMS, Connolly dan Begg, 2010

Data yang menjadi acuan pangkalan data rancangan tersebut berasal dari 3 (tiga) macam sumber, antara lain:

1. Spesimen paspor, merupakan diseminasi yang dilakukan negara atas kerja sama bilateral, dan dapat berupa pertukaran database paspor di negara masingmasing.

2. Prado Passport, merupakan sumber database passport yang telah disediakan oleh European Council dan dapat diakses secara bebas (https://www.consilium.europa.eu/prado/en/).

3. Edison Travel Document, merupakan sumber database passport yang berisi informasi mengenai pasporpaspor asing dari berbagai negara dan dapat diakses secara bebas (http://www.edisontd.net/).

Proses pemeriksaan rancangan sistem pendeteksian paspor tersebut dapat dilaksanakan dengan metode jaccard measure (konsep auto matching) [42] yang berfungsi untuk mengetahui tingkat kemiripan dalam proses pemeriksaan paspor di TPI.

Hasil diagram alir ini dibuat berdasarkan metode SDLC dalam batas communication, planning, dan modelling. Pada setiap alur di atas, pengintegrasian sistem pemeriksaan paspor palsu telah dirancang secara mendasar berdasarkan kumpulan pangkalan data paspor yang telah dibuat secara terpusat. Dengan adanya rancangan tersebut, maka proses pemeriksaan keimigrasian di TPI dapat dilakukan oleh petugas imigrasi secara otomatis melalui sistem pendeteksian paspor palsu (berdasarkan rekomendasi rancangan) dengan konsep verifikasi secara otomatis atau auto-matching system.

\section{KESIMPULAN}

Penelitian ini memberikan penjelasan dan fakta bahwa peran dan cara kerja petugas imigrasi di TPI dalam mengidentifikasi paspor palsu melalui sistem APK belum dapat menghasilkan suatu hasil yang optimal. Penyebabnya adalah keterbatasan sistem APK yang belum memiliki sistem pendeteksian paspor palsu, sehingga petugas imigrasi mengandalkan insting dan kemampuan analisis dalam pengidentifikasian keaslian suatu paspor.

Proses pendeteksian dan verifikasi keaslian sebuah paspor oleh petugas melalui sistem APK belum memberikan hasil yang akurat, karena waktu proses pemeriksaan keimigrasian di konter imigrasi relatif sangat cepat karena jumlah penumpang yang banyak. Petugas imigrasi di TPI tidak memiliki pangkalan data paspor di berbagai negara sebagai data pembanding.

Peran dan cara kerja sistem APK di TPI belum dapat mengidentifikasi paspor palsu. Sebab, pada implementasinya sistem APK saat ini hanya dapat mengidentifikasi hasil cekal melalui proses pemindaian MRZ. Petugas imigrasi di TPI sangat dituntut untuk lebih fokus dan bergantung pada analisis kemampuan individu dalam memeriksa keaslian paspor. Padahal, sistem APK telah dilengkapi dengan alat pemindai paspor (document reader/scanner) yang memiliki sinar $\mathrm{UV}$, infrared, dan RFID.

Rancangan sistem pendeteksian paspor palsu yang telah menjadi hasil penelitian masih memerlukan beberapa proses implementasi pengujian serta pembuatan program versi BETA yang mana hal tersebut merupakan sebuah keterbatasan yang terdapat dalam penelitian ini. Keterbatasan tersebut menjadi sebuah tantangan yang kemudian dapat dilaksanakan pada penelitian selanjutnya untuk mengimplementasikan rancangan model sistem pendeteksian paspor palsu tersebut dalam bentuk fisik dan nyata.

\section{UCAPAN TERIMA KASIH}

Ucapan terima kasih kami haturkan kepada Politeknik Imigrasi, Depok, Indonesia sebagai institusi asal tim penulis yang telah memberikan dukungan kepada tim penulis melaksanakan implementasi Dharma Perguruan Tinggi penelitian untuk berkarya sebagai akademisi di Indonesia. Kemudian ucapan terima kasih pun turut kami sampaikan kepada Kementerian Hukum dan Hak Asasi Manusia yang telah memberikan ruang bagi kami untuk melakukan diseminasi ilmu pengetahuan.

\section{DAFTAR PUSTAKA}

[1] N. H. Pratama, Yulianti, and A. S. Sukamto, "Aplikasi Bank Materi Pembelajaran untuk Jenjang SMA,” J. Sist. dan Teknol. Inf., vol. 8, no. 3, pp. 257-263, 2020, [Online]. Available: https://jurnal.untan.ac.id/index.php/justin/article/view/31984.

[2] Asbianto, H. Nasution, and M. A. Irwansyah, "Rancang Bangun Aplikasi Pengolahan Data Perusahaan Mining Consultan CV. Mitra Mineral," J. Sist. dan Teknol. Inf., vol. 8, no. 2, pp. 149-159, 2020, [Online]. Available: https://jurnal.untan.ac.id/index.php/justin/article/view/37998.

[3] F. Triana, J. Endri, and I. Salamah, "Implementasi Teknik Kriptografi CAESAR CIPHER Untuk Keamanan Data Informasi Berbasis Android," RESTI (Rekayasa Sist. dan Teknol. Informasi), vol. 4, no. 4, pp. 627-634, 2020, [Online]. Available:

http://jurnal.iaii.or.id/index.php/RESTI/article/view/1984

[4] Association of Certified Fraud Examiners, "The Fraud Triangle," 2020. https://www.acfe.com/fraud-triangle.aspx. [5] Undang-Undang Republik Indonesia Nomor 25 Tahun 2009 
Tentang Pelayanan Publik. Indonesia, 2009.

[6] Undang-Undang Republik Indonesia Nomor 6 Tahun 2011 Tentang Keimigrasian. Republik Indonesia, 2011.

[7] E. Nachrowi, Y. Nurhardryani, and H. Sukoco, "Evaluation of Governance and Management of Information Technology Services Using Cobit 2019 and ITIL 4," RESTI (Rekayasa Sist. dan Teknol. Informasi), vol. 4, no. 4, pp. 764-774, 2020, [Online]. Available:

http://jurnal.iaii.or.id/index.php/RESTI/article/view/2265.

[8] Peraturan Direktur Jenderal Imigrasi Nomor IMI.459.GR.01.02 Tahun 2011 Tentang Standar Operasional Prosedur Border Control Management (BCM). Indonesia, 2011.

[9] G. Budiartie, "Imigrasi Pasang Alat Baru untuk Cegah Penjahat Lolos ke Luar Negeri," 2010 https://nasional.tempo.co/read/240842/imigrasi-pasang-alatbaru-untuk-cegah-penjahat-lolos-ke-luar-negeri/full\&view=ok .

[10] International Civil Aviation Organization, ICAO Doc. 9303.

[11] The International Criminal Police Organization, Stolen and Lost Travel Documents Database. .

[12] F. Tri Ardiansyah, Imigrasi di Batas Imajiner. Tangerang, 2016

[13] J. Tettey, "UNODC releases guide to strengthen examination of documents at borders," 2011.

https://www.unodc.org/unodc/en/frontpage/2011/January/unod c-releases-guide-to-strengthen-border-examination-ofdocuments.html.

[14] B. Schouten and B. Jacobs, "Biometrics and their use in epassports," Image Vis. Comput., vol. 27, 2011, [Online]. Available: www.elsevier.com/locate/imavis.

[15] H. Esteves, "Introduction to Fraudulent Methods used in Travel, Identity, and Visa Documents," 2012.

[16] UNODC, "Border Management," 2020.

https://www.unodc.org/southeastasiaandpacific/en/what-wedo/toc/border-management.html.

[17] Tim Humas Kanwil NTB, "Kakanwil : Empat Hal Yang Wajib Diketahui dan Dikuasai Petugas Imigrasi di TPI," 2017. https://ntb.kemenkumham.go.id/berita-kanwil/beritautama/2701-kakanwil-empat-hal-yang-wajib-diketahui-dandikuasai-petugas-imigrasi-di-tpi (accessed Mar. 31, 2020).

[18] W. Suharso, Q. A'yun, and D. Arifianto, "Pengembangan Sistem Deteksi Kesesuaian Dokumen Proposal Program Kreativitas Mahasiswa Dengan Metode Extended Weighted Tree Similarity," JUSTINDO (Jurnal Sist. dan Teknol. Inf. Indones., vol. 2, no. 2, pp. 84-91, 2017, doi: https://doi.org/10.32528/justindo.v2i2.1044.

[19] G. A. Bowen, "Document Analysis as a Qualitative Research Method," Qual. Res. J., vol. 9, no. 2, pp. 27-40, 2009.

[20] J. Murray, "Cloud network architecture and ICT - Modern Network Architecture," 2011.

[21] P. Diat Lantip and Riyanto, Teknologi Informasi Pendidikan. Yogyakarta: Gava Media, 2011.

[22] B. Warsita, "Landasan Teori dan Teknologi Informasi dalam Pengembangan Teknologi Pembelajaran," Teknodik, vol. XV, 2011, [Online]. Available:

https://jurnalteknodik.kemdikbud.go.id/index.php/jurnalteknod ik/article/view/91.

[23] C. T. Wibowo, "Efektivitas Pelayanan Pembuatan Paspor Dengan Menggunakan Sistem Informasi Manajemen Keimigrasian (SIMKIM) Di Kantor Imigrasi Kelas I Kota Tangerang," Universitas Sultan Ageng Tirtayasa, 2014.

[24] Direktorat Jenderal Imigrasi, "Pelaksanaan Sistem BCM sebagai Sarana Pencegahan Imigran Ilegal yang Handal,” 2010.

L. Suprajadi, "Teori Kecurangan, Fraud Awareness dan Metodologi untuk Mendeteksi Kecurangan Pelaporan Keuangan," Bina Ekon. Maj. llmiah Fak. Ekon. Unpar, 2014, [Online]. Available: https://www.onesearch.id/Record/IOS807.article-722/TOC.

[26] D. R. Cressey, Other People's Money. Montclair, N.J.: Patterson Smith, 1973.

[27] International Civil Aviation Organization, International Civil Aviation Organization: Facilitation. 2015.

[28] Peraturan Menteri Hukum Dan Hak Asasi Manusia Nomor 8 Tahun 2014 Tentang Paspor Biasa dan Surat Perjalanan Laksana Paspor. Indonesia, 2014.

[29] Peraturan Menteri Hukum dan HAM Nomor 44 Tahun 2015
Tentang Tata Cara Pemeriksaan Masuk dan Keluar Wilayah Indonesia Di Tempat Pemeriksaan Imigrasi. Indonesia, 2015.

[30] G. Putri, "Dirjen Imigrasi Akui Banyak Celah Keluar Masuk Dimanfaatkan Oknum," Law Justice, 2020. https://www.lawjustice.co/artikel/89372/dirjen-imigrasi-akui-banyak-celahkeluar-masuk-dimanfaatkan-oknum/.

[31] National Career Services, "Immigration Officer," 2020. https://nationalcareers.service.gov.uk/jobprofiles/immigration-officer.

[32] D. Romi, "Pejabat ini Tegaskan Fungsi Pemeriksaan Imigrasi," Sumeks.Co, 2020. https://sumeks.co/pejabat-ini-tegaskanfungsi-pemeriksaan-imigrasi/.

[33] M. Gariup and G. Soederlind, "Document Fraud Detection at the Border," in European Intelligence and Security Informatics Conference, 2013, pp. 231-238, [Online]. Available: https://ieeexplore.iee.org/abstract/document/6657173/.

[34] A. Susanto, Sistem Informasi Akuntansi. Bandung: Lingga Jaya, 2013.

[35] R. Ariani Sukamto and M. Shalahudin, Rekayasa Perangkat Lunak Struktur dan Berorientasi Objek. Bandung: Informatika, 2014.

[36] T. Connolly and C. Begg, Database Systems: A Practical Approach to Design, Implementation, and Management. Pearson, 2010

[37] R. Ariani Sukamto and M. Shalahudin, Rekayasa Perangkat Lunak Struktur dan Berorientasi Objek. Bandung: Informatika, 2014.

[38] D. Patel, Balakarthikeyan, and V. Mistry, "Border Control and Immigration on Blockchain," in International Conference on Blockchain, 2018, pp. 166-179, [Online]. Available: https://link.springer.com/chapter/10.1007/978-3-319-944784_12.

[39] Sucipto, "Perancangan Active Database System pada Sistem Informasi Pelayanan Harga Pasar," J. INTENSIF, vol. 1, no. 1, pp. 35-43, 2017, [Online]. Available:

https://ojs.unpkediri.ac.id/index.php/intensif/article/download/ $562 / 435$.

[40] V. Patel, "Airport Passenger Processing Technology: A Biometric Airport Journey," Embry-Riddle Aeronautical University, 2018.

[41] T. P. D. Tjandra, "Pembuatan Website UD. Tjandra Utama Jaya," Universitas Dinamika, 2012.

[42] R. Octaviana, "Sistem Auto Matching Dokumen Proposal Tugas Akhir Berbahasa Indonesia Menggunakan Jaccard Measure," Universitas Muhammadiyah Jember, 2017. 